\title{
Shariah Compliance in Islamic Economics: A Bibliometric Analysis
}

\author{
Muhammad Sholihin ${ }^{a}$ \\ IAIN Curup, Indonesia \\ Ramsah Alib \\ IAIN Takengon, Indonesia \\ Deri Wantoc \\ IAIN Curup, Indonesia
}

\begin{abstract}
This study aims to examine the literature related to shariah compliance in the Scopus database. Furthermore, classification and critical commentary were applied to find a new direction for developing studies on shariah compliance in Islamic economics. The bibliometric approach was used to analyse 233 articles, while a systematic literature review was used to classify issues from 82 articles on this paradigm. The results showed that the examined studies grew significantly and were influential in developing the shariah compliance paradigm. This was indicated by the author's highest $\mathrm{m}$-index of 0.666 . However, this literature primarily concerns financial institutions and their relationship with the paradigm, followed by related literature in various industries, with extensive discussion on ethics and in the normative context. In this regard, shariah compliance issues can be classified into three topics, namely Islamic banks, non-bank financial institutions, and general firms. Shariah compliance was insufficiently used as an instrument to measure the product restructuring impact of an Islamic bank and a reflection of the compliance from the customer psychology perspective. In this context, it is necessary to transform the paradigm into "preventing exploitation" by introducing the customer exploitation index.
\end{abstract}

Keywords: Shariah compliance, maqasid shariah, preventing exploitation, exploitation index, Islamic financial institutions

JEL classification: G00, G20, G21

a Faculty of Shariah and Islamic Economics, Institut Agama Islam Negeri (IAIN) Curup, Rejang Lebong, Indonesia. Apart from being a lecturer, the author is currently a doctoral student at Program Study of the Islamic Economy and Halal Industry, Sekolah Pascasarjana Universitas Gadjah Mada, Yogyakarta, Indonesia. Email: sholihin@iaincurup.ac.id.

b Faculty of Tarbiyah, IAIN Takengon, Aceh Tengah, Indonesia. Email: ramsah2584@gmail.com

c Faculty of Tarbiyah, Institut Agama Islam Negeri (IAIN) Curup, Rejang Lebong, Indonesia. Email: deriwanto@iaincurup.ac.id

Article Info: Received 23 May 2021; Revised 17 August 2021; Accepted 29 September 2021 https://doi.org/10.22452/MJES.vol58no2.7 


\section{Introduction}

Shariah compliance is a theoretical framework used to evaluate the commitment of the Islamic finance industry to shariah values. It is also the foundation for the profit and loss sharing model implemented in Islamic banks (Mansoor et al., 2020). This shows that it has an essential position in the finance industry. There are several arguments on why the paradigm is considered necessary in Islamic finance. First, it is a framework for product differentiation (Ullah, 2014), and second, it is an institutional foundation for the banks (Abbas et al., 2009; Balli, Chowdhury, et al., 2020; Cheong, 2021). These two arguments are the ontological dimension of why compliance is essential for Islamic finance (Kammer et al., 2015). Other reasons for the importance can be identified from various Islamic financial institutions' efforts to prioritise it in their operations.

Anwer et al. (2020) showed that Iran, Sudan and Pakistan represent the Muslimmajority countries as regulators of shariah compliance. Also, Hanif (2018) studied a more specific focus. Based on four assessment categories, namely portfolio construction, access to finance, reputation, and shariah governance, it was concluded that the Islamic finance industry in Malaysia, Pakistan, Bahrain and Indonesia was dynamic in compliance performance. This is due to the different measurement indicators in each country, especially concerning the four dimensions identified by Hanif (2018). Akguc and Al Rahahleh (2018) categorised Bahrain as the country in the Gulf that had the highest compliance with the principles of shariah. Several dynamic empirical studies of this paradigm confirmed its importance and the high interest of scholars towards it.

Several related issues studied by scholars can be divided into a few classifications. First is shariah compliance in Islamic banks. A set of studies classified in this first group generally examined three main issues, namely (1) it is used as a framework for understanding consumer attitudes and behaviour towards Islamic banks, (2) shariah compliance impact on the banks, and (3) measurement of the Islamic banks' commitment in operationalising the paradigm (Ahmed \& Farooq, 2018; Johan et al., 2020; Julia et al., 2016; Mansoor et al., 2020; Rosly et al., 2017; Trakic, 2020). Second is shariah compliance in the non-bank financial industry. Several issues were discussed, such as (1) it is the foundation of the assumption, (2) it is the measurement for Islamic values, and (3) it is the co-factor that affects the performance of non-bank financial institutions (Ahmed \& Farooq, 2018; Hazny et al., 2020; Kasim, 2012; Mustapha et al., 2019). Third is shariah compliance in the industry in general, which includes sets of issues as follows: (1) it is an ethical framework supporting companies in various economic challenges, (2) consumer compliance behaviour towards shariah values, (3) it is a variable that affects company behaviour, and (4) the function of shariah compliance in the company (Akinsomi et al., 2014; Cheong, 2021; Sharif et al., 2020). The three existing areas of this paradigm showed that it was difficult to obtain literature that specifically elaborates on shariah compliance using a bibliometric approach. Therefore, this study was conducted to fill the gap by answering the following questions:

Q1. What are the conceptual structure map and network mapping of shariah compliance published in international journals indexed by Scopus?

Q2. How are shariah compliance topics in Scopus-indexed journals classified? 
Q3. What paradigm is required to be developed to support shariah compliance as an Islamic economic development agenda?

This article is structured in six sections which contain the following: (i) an introduction which contains the background, objectives, or research questions, (ii) an exploration of the literature of shariah, (iii) a methodology of bibliometric and systematic literature review including design as well as data analysis methods, (iv) results that narrated several aspects that cover the most relevant keywords and sources, authors index, shariah compliance topics, conceptual structure map, author's highest contributions, as well as the classification of shariah compliance issues based on the systematic literature review approach, (v) a discussion of the existing topics on shariah compliance as well as the development of its concept at the micro and macro levels of Islamic economics, and (vi) concluding remarks and limitations of the study.

\section{Literature Review}

Jalil and Osman (2019) stated that shariah compliance is a concept that has existed since 1983. It was marked by the issuance of "The Islamic Banking Act" on March 10,1983 . Subsequently, the Malaysian government has issued several regulations to introduce "shariah compliance" into the Islamic legal framework. However, the paradigm was legally identified in the country through the legislation of Islamic banks. In addition, its forerunner was obtained by establishing the first Islamic bank globally, i.e., the Dubai Islamic Bank, in 1975. Two years later (1977), two Islamic banks were established under the Faysal Islamic Bank in Egypt and Sudan. In the same year, the Kuwaiti government established the Kuwait Finance House. Meanwhile, at the international level, Egypt initiated the Islamic Development Bank and the proposal was delivered in 1970 at the delegation of foreign ministers meetings for Islamic countries in Karachi (Alharbi, 2015). The historical facts prove that shariah compliance was born simultaneously.

Trust in this paradigm, especially in Malaysia, increased during the economic crisis from 2008-2009. Several studies indicated that Islamic finance is better prepared to face financial and economic crises than conventional finance (Guyot, 2011). This is consistent with Alam and Rajjaque (2010), who affirmed that this framework enabled Islamic banks to outperform the market during 2008-2009. It encouraged scholars to be more thorough when elaborating the concept. In Malaysia and other countries, the scholars successfully came out with a set of arguments behind the excellence of Islamic finance based on shariah compliance as follows: 1) In qualitative aspects, the process of formulating an operational framework for the financial industry based on Islamic values is to eliminate non-compliance industrial practices, 2) in quantitative aspects, the operational, product and financial management of Islamic bank consistently consider the rules of the shariah board (Cheong, 2021). In addition, Arliza et al. (2016) emphasised that the development of shariah compliance in these banks is to build a good image as an Islamic prototype bank.

Therefore, Arliza et al. (2016) introduced three aspects of screening the paradigm in Islamic finance industries. First, business activities involve the screening of Islamic 
financial operations related to non-compliance, i.e., gambling, liquor and pork-related activities, as well as non-halal food and beverages. This is to ensure that there is no element of usury in making a profit. In this context, the high cost of financing Islamic banks is still tolerated as a natural behaviour in Islam. The second aspect is financial ratios. In this regard, the AAOIFI (Accounting and Auditing Organization for Islamic Financial Institutions) offers several essential rules of financial ratios for the Islamic finance industry, such as 1 ) interest taking deposits less than $30 \%$ of market capitalisation of total equity, 2) interest-bearing debt less than $30 \%$ of market capitalisation of the corporation, and 3) total market value of illiquid assets more than $30 \%$ of market value of the total assets (Arliza et al., 2016; Ayedh et al., 2019). Third, shariah financial governance focuses on organisational structures of shariah compliance in an Islamic bank. In this case, functions of the Shariah Supervisory Board of Islamic financial institutions in supervising the Islamic banks need to be evaluated consistently. These aspects indicated shariah compliance is implemented at two systemic levels, where the first is the paradigmatic level. In this context, it is an operational framework of the Islamic finance industry (Muhamad, 2011). Second is the management and operational level industry (Azam et al., 2019). Therefore, physically and in principle, Islamic as well as conventional banks can be distinguished from each other.

Moreover, Akguc and Al Rahahleh (2018) showed that the implementation of this paradigm influences companies operating in Islamic countries. In this regard, Farooq and Alahkam (2016) concluded that the performance of shariah based companies was non-Islamic. Mansoor et al. (2020) indicated that Islamic banks can access more significant sources of funds because of the shariah commitment. Furthermore, Rahayati et al. (2020) successfully discovered the effect of dividends in sustaining corporate governance and social responsibility on the performance of shariah-compliant companies. Ullah (2014) showed that the status of this paradigm was vulnerable in Bangladesh because of its implementation in banks, i.e., lack of knowledge, seriousness and attention to shariah audits and weak supervision system. Therefore, shariah compliance is not limited to how it is applied to the financial industry per se. However, it deserves to be elaborated in a more substantial direction and refers to the actors involved in shariah economic institutions. In principle, this last issue is minimal and has not been worked out properly or systematically. Therefore, Islamic economists need to develop studies in that regard, such as the paradigm of preventing exploitation as the primary goal of why Islamic banks' Islamisation is carried out.

\section{Methodology}

This study aims to: 1) quantify the development in the literature related to shariah compliance in Scopus indexed international journals by using bibliometric analysis (Aria \& Cuccurullo, 2017), and 2) classify the issues studied by Islamic economics scholars related to shariah compliance by applying the systematic literature review. The statistical information that can be obtained through bibliometric technique taxonomy is as follows: 1) bibliographic coupling - the unit of analysis includes the authors, documents, and journals, 2) co-citation - this analyses co-cited authors and journals, 3) co-author - this establishes the author's co-occurrence in the list of a document, 
and 4) co-word - this analyses the co-occurrence of terms in a document (Aria \& Cuccurullo, 2017). The bibliometric approach was helpful to capture issues in the development of shariah compliance.

The differences between bibliometric analysis and systematic literature review are given in Table 1. Figure 1 explains the processes involved in each of these approaches. The bibliometric analysis of this study was applied in three stages i.e., data collection, analysis and visualisation (Aria \& Cuccurullo, 2017; Kraus et al., 2020). It can be classified into a set of procedures which include, first, data collection. The data were entirely obtained from the Scopus database through a search engine that was provided by Scopus. A set of keywords (i.e., "shariah compliance") were used to compile the metadata. This study only utilised articles from reputable international journals as text or data sources. The process was named "data loading," which generated metadata in a "bib" extension. Subsequently, in the conversion stage, the data were converted to an $R$ data frame. The second stage is data analysis which has three sub-stages, namely 1 ) descriptive analysis of a bibliographic data frame, 2) network creation for bibliographic coupling, co-citation, collaboration and co-occurrence analyses, and 3) normalisation which is a process of benchmarking that is needed to enhance comparability across diverse scientists, fields, papers, time and period (Bornmann, 2020). Subsequently, data reduction was applied to help in identifying subfields (Aria \& Cuccurullo, 2017). The third stage is data visualisation which consists of several processes, such as 1 ) conceptual structure mapping, and 2) networking mapping (Aria \& Cuccurullo, 2017).

The systematic literature review consists of a set of procedures. First, the data search used the Scopus database and ran a single keyword "shariah compliance". The process resulted in 233 journal articles indexed by Scopus. It is per the function of systematic literature review as a theme-centric review that can help the research

Table 1. Differences between bibliometric and systematic literature review

\begin{tabular}{|c|c|c|}
\hline & Bibliometrics & Systematic literature review \\
\hline Definitions & $\begin{array}{l}\text { The application of mathematical and } \\
\text { statistical techniques to analyse the } \\
\text { patterns that appear in publications } \\
\text { and documents }\end{array}$ & $\begin{array}{l}\text { Qualitatively summarises evidence on a } \\
\text { topic using informal or subjective } \\
\text { methods to collect and interpret studies }\end{array}$ \\
\hline Goals & $\begin{array}{l}\text { To evaluate academic outcomes } \\
\text { quantitatively, which has started } \\
\text { threatening practice-based studies }\end{array}$ & $\begin{array}{l}\text { Provides a summary or an overview of the } \\
\text { topic }\end{array}$ \\
\hline Source & $\begin{array}{l}\text { Platforms provide web interfaces } \\
\text { with basic or advanced search } \\
\text { options and essential analytical } \\
\text { tools, as well as APIs for automated } \\
\text { search or data collection }\end{array}$ & $\begin{array}{l}\text { Comprehensive source, explicit search } \\
\text { approach }\end{array}$ \\
\hline Selection & $\begin{array}{l}\text { Through representative journals in } \\
\text { the most relevant disciplines }\end{array}$ & $\begin{array}{l}\text { Criterion-based selection, uniformly } \\
\text { applied }\end{array}$ \\
\hline Synthesis & Quantitative & Quantitative/Qualitative \\
\hline
\end{tabular}




\section{1: Bibliometric Analysis}

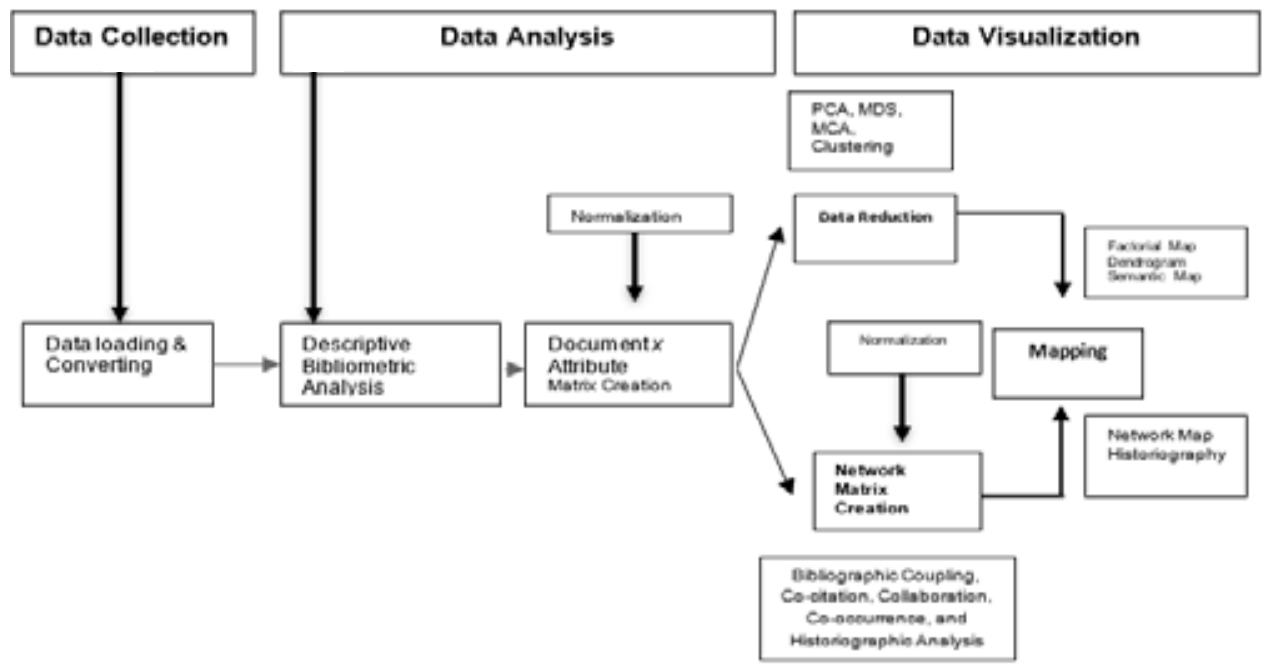

\section{2: Systematic Literature Review}

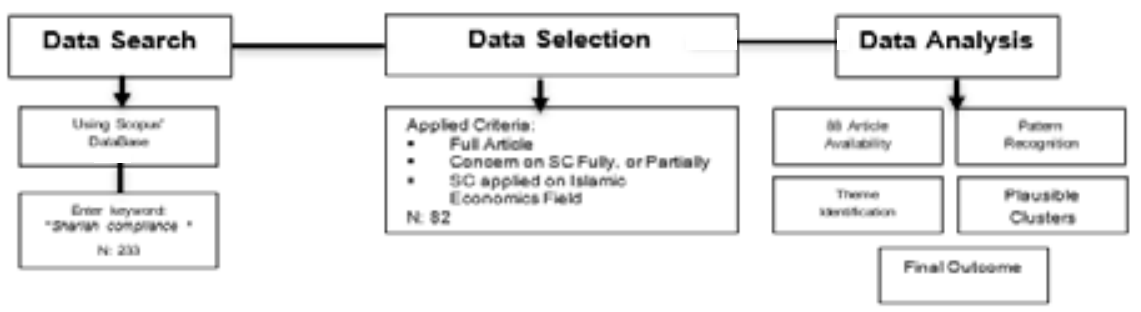

Figure 1. Design of study

team to obtain articles and systematically understand them in-depth through a review (Fisch \& Block, 2018; Indarti \& Lukito-budi, 2020; Nomran \& Haron, 2019). Second is data selection where a selection from the initial 233 articles was conducted based on the following criteria: 1) the paper should be an entire article, and 2) filter article by reading the abstract and determining "inclusion" or "exclusion." This process identified 82 articles which would later be classified according to an issue. Third is data analysis where the authors applied the content analysis modelled by Miles and Huberman (1994), with at least four stages as follows:

(i) a specific theme was identified for each paper according to its abstract, objectives, research question(s) and results,

(ii) the identified themes were further investigated to identify possible patterns and develop appropriate discussion topic clusters within the theme to represent those patterns,

(iii) assessing the articles to recognise any plausibility among the patterns and infer different discussion topics within each theme. Accordingly, each theme per 
paper was added into a cluster, and a discussion topic cluster was used as a baseline for further interpretation, and

(iv) based on the resulting baseline, data analysis and interpretation were conducted using an input-process-output (IPO) framework.

\section{Results}

\subsection{Descriptive Analysis on Shariah Compliance Literature}

Based on the bibliometric analysis, the most relevant top ten keywords related to shariah compliance are obtained. The author keyword (D.E.) "Islamic finance" was used by 56 articles, with the keyword-plus (I.D.) "Malaysia" used by seven articles. In relation, "corporate governance," was only used by nine articles, while the keywordplus "Islamism", "risk management", and "industry" were used by two studies. The use of "shariah compliance" was dominantly discussed in the scope of Islamic finance (Amin \& Hamid, 2018; Kaakeh et al., 2019; Kahf \& Al-Saudi, 2016; Miskam et al., 2017). Publication sources were relatively varied in the journal, i.e., journal with a focus on the scope of economics, as well as conventional and Islamic finance. Journal of Islamic Accounting and Business Research published at least 24 articles on shariah compliance. Pengurusan was the tenth journal with several articles related to this keyword. Meanwhile, only four articles were published about shariah compliance until 2020. This indicated that the paradigm was examined based on interdisciplinary studies (Majid et al., 2015). It was certainly effective on the reputation of scholars who carried out the study. This implication can be identified from the h-index, g-index, and total citation obtained by article authors (see Table 2 ).

Hassan (2011) was relatively higher than all the other authors in the aspects of indicators as a writer, i.e., h-index, g-index, m-index, total citation (TC) and the number of publications (NP). The last position among the ten authors was Akguc (2018), with three articles in 2018. Hassan MK's m-index was 66.6\%, which indicated the growth of shariah compliance as the number of studies increased essentially across different

Table 2. Authors index

\begin{tabular}{clcccrcr}
\hline No. & Authors & h-index & g-index & m-index & TC & NP & PY-Start \\
\hline 1. & Hassan MK & 4 & 6 & 0.666 & 43 & 8 & 2016 \\
2. & Hassan R & 1 & 1 & 0.090 & 3 & 6 & 2011 \\
3. & Farooq O & 3 & 5 & 0.375 & 41 & 5 & 2014 \\
4. & Hussain HI & 3 & 4 & 0.750 & 19 & 5 & 2018 \\
5. & Ahmed H & 2 & 2 & 0.222 & 7 & 4 & 2013 \\
6. & Choudhury MA & 2 & 3 & 0.285 & 11 & 4 & 2015 \\
7. & Muneeza A & 1 & 1 & 0.333 & 4 & 4 & 2019 \\
8. & Aboulaich R & 1 & 2 & 0.142 & 5 & 3 & 2015 \\
9. & Ahmad AUF & 1 & 3 & 0.166 & 11 & 3 & 2016 \\
10. & Akguc S & 2 & 2 & 0.500 & 8 & 3 & 2018 \\
\hline
\end{tabular}


fields, i.e., Islamic finance, the industry, real estate and hotel management. For example, Merdad et al. (2016) were more interested to study the topic in the context of whether religious belief can become the foundation of investigation in Saudi Arabia. El-Gohary (2016) critically examined whether halal tourism was entirely driven by shariah compliance and its effectiveness on the transportation industry in Islamic countries. These two articles present arguments with the view that the shariah compliance paradigm grows significantly as a field of study in the interdisciplinary context.

Figure 2 and Figure 3 indicated the topics of shariah compliance that appeared in the articles in Scopus indexed international journals. Figure 2 showed that they were interrelated. Substantially, there are at least three groups of topics (Figure $3)$, where the first included relationship between regression analysis, investments, risk-sharing, risk management and commerce (Ahmed \& Farooq, 2018; Amaroh \& Masturin, 2018; Jobst, 2009; Kammer et al., 2015; Kusuma, 2019). The second group represented a simultaneous relationship among the stock market, financial institutions, Islamism, shariah, banking, Malaysians, industry and Malaysia (Ahmed \& Farooq, 2018; Hassan et al., 2018; Norbayusri Baharudin et al., 2020; Paranque \& Erragragui, 2016; Shamsudheen \& Rosly, 2020; Umar et al., 2018). Meanwhile, the third group represented the interrelationships among information management, business activities, economic and social effect, insurance, as well as sustainable development (Ahmed \& Farooq, 2018; Heradhyaksa \& Markom, 2018; Kasim et al., 2016; Nugraha et al., 2020; Yahya \& Mahzan, 2011). At a broader level, each group also had a specific relationship in terms of issues and perspective (Figure 2). This indicated that the writers successfully influenced others as a reference of scientific foundation in developing shariah compliance.

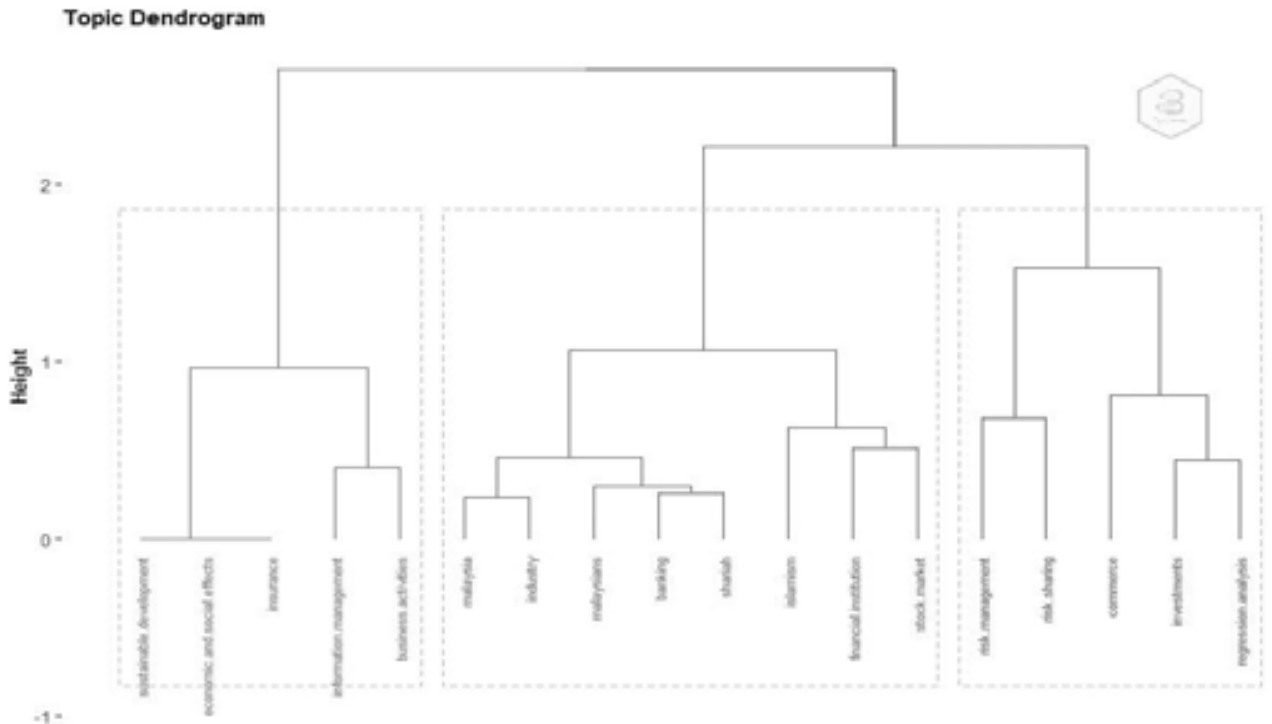

Figure 2. Shariah compliance topics 


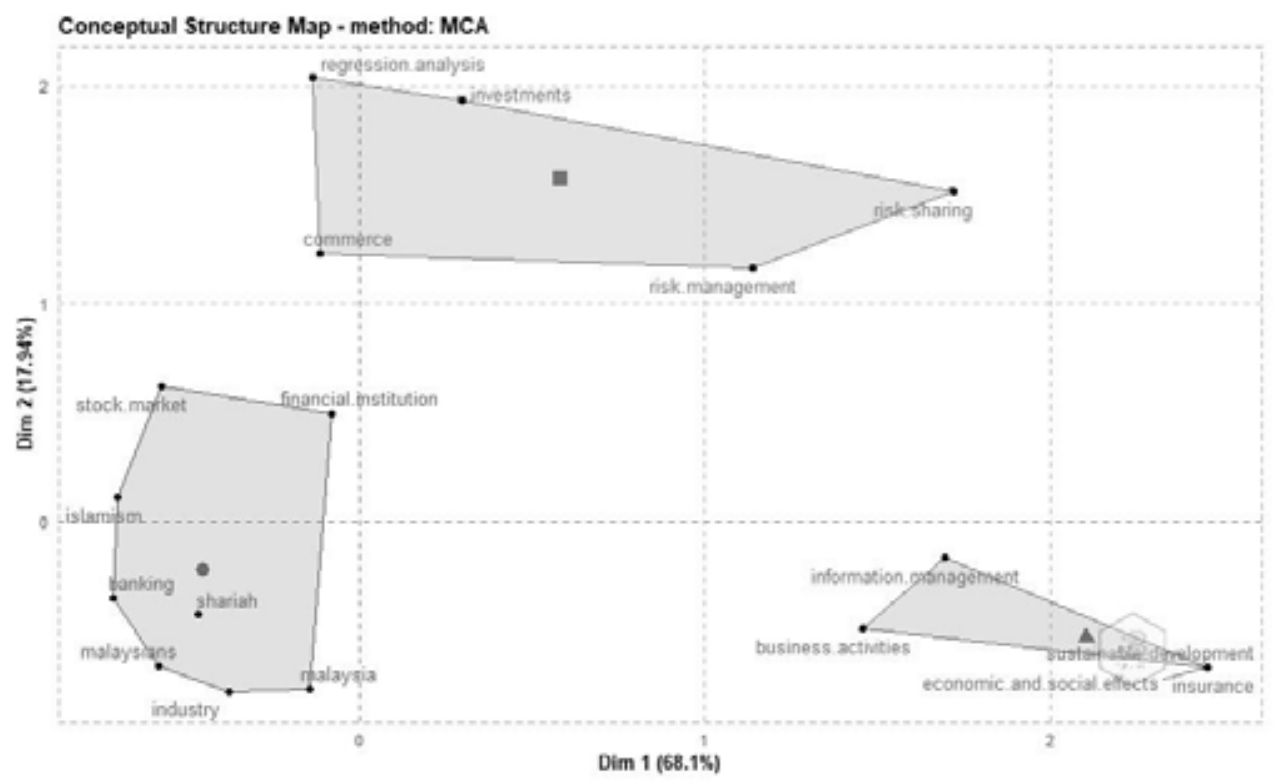

Figure 3. Conceptual structure map

Figure 4 showed three clusters of authors as the most significant contributors. In this condition, Hussain et al. (2020) identified the impact of shariah compliance on the capital structure of companies in Malaysia, and the study was included in the third cluster. It also classified Umar et. al. (2018) in "cluster3", who successfully showed that the Islamic stock market had a negative return on interest rates. Noor et al. (2011) was included in the first cluster, who successfully identified that transparency in muamalah (Islamic business law) contracts were necessary. Daud (2017), who was also positioned in the first and second clusters, showed that takaful rules as well as the regulations of Malaysia and Indonesia were governed by the Islamic Financial Services Act 2013 (IFSA 2013) and Law No 40 (UU40) respectively (Daud, 2017).

In summary, bibliometric analysis has at least succeeded in identifying a set of shariah compliance aspects. First, shariah compliance was studied from a broad perspective, i.e., fiqh-normative analysis, the discipline of economics and Islamic finance. Second, it was studied from an interdisciplinary perspective and published in various journals, i.e., economics and financial journals. Third, its development issue was quite significant. A reasonably high index achievement was indicated by the authors of articles related to the concept of shariah compliance. For example, Hassan (2016) had an m-index reaching 0.666. This indicated that the writer had reasonably high productivity according to the $\mathrm{h}$-index and the duration of publications related to the theoretical framework (Ingale \& Paluri, 2020). Fourth, shariah compliance was concentrated in Islamic financial institutions. In this regard, it should be extended beyond the field of Islamic financial industries. A systematic literature review can be the best solution for that purpose. 


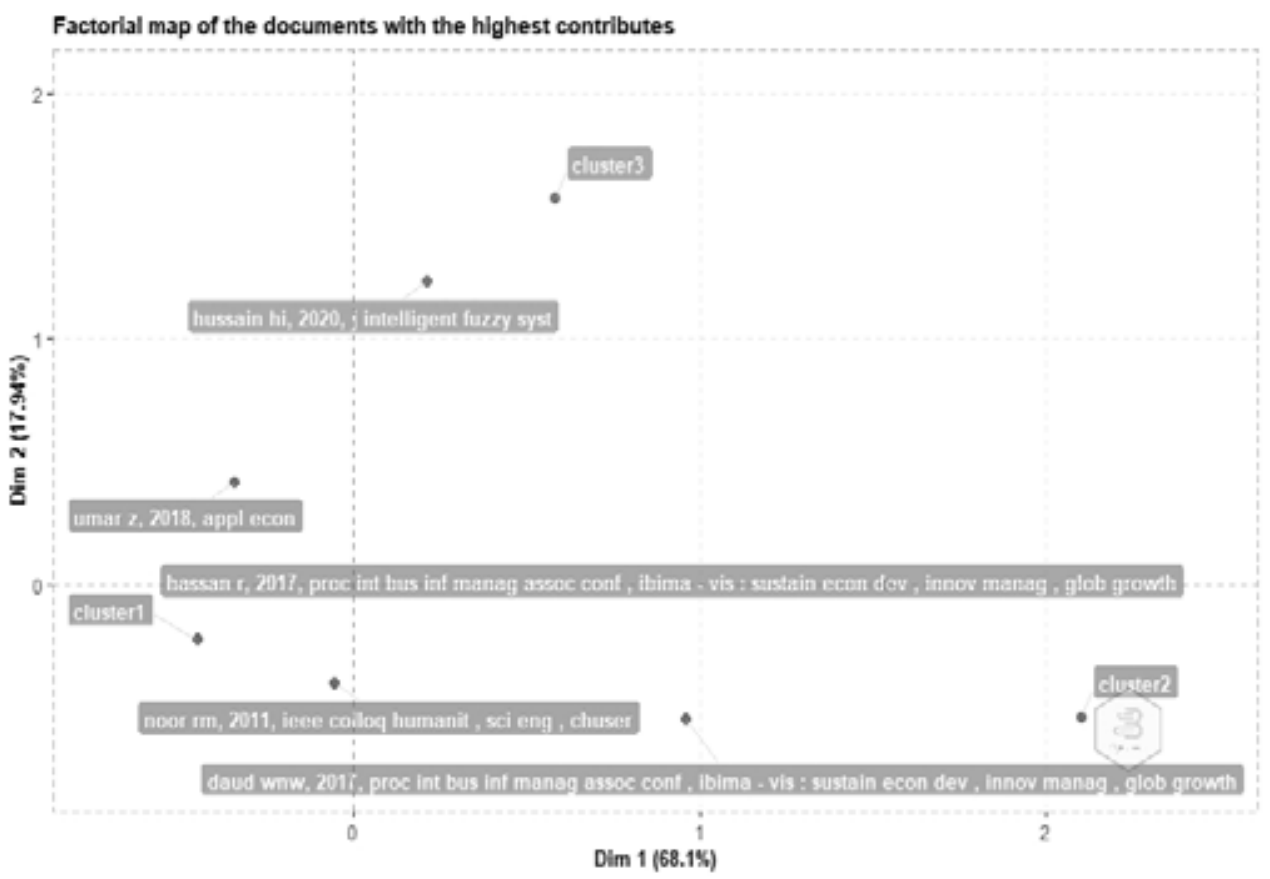

Figure 4. Author's highest contribution

\subsection{Shariah Compliance: An Initial Classification}

The issues in existing literature presumably can be classified as shariah compliance in (i) bank financial institutions, (ii) non-bank financial institutions, and (iii) other industries, such as hotels and halal tourism. The classifications were obtained from a critical analysis of 84 articles, as illustrated in Figure 5.

The first classification is shariah compliance in Islamic banks. In this context, the concept can be grouped into three issues as follows:

(i) the shariah compliance studies on customers' behaviour towards Islamic banks. In this regard, Mansoor et al. (2020) affirmed that Islamic banks were more effective in raising funds because of their commitment to shariah values. Kaakeh et al. (2019) stated that the compliance concept was simultaneously practical on the behaviour and interests of Islamic bank customers, especially in the United Arab Emirates. Moreover, Baber (2019) more profoundly showed that shariah compliance significantly affected customer satisfaction in using FinTech services or financial technology. In other words, the implementation of shariah values in these banks directly influences customer perceptions and behaviour towards them (Ehsan Wahla et al., 2018; Haque et al., 2010; Johan et al., 2020; Saqib et al., 2016; Sawari et al., 2011),

(ii) Shariah compliance studied on its status and functions for Islamic banks. Some literature has elaborated on these functions. For example, Trakic (2020) 


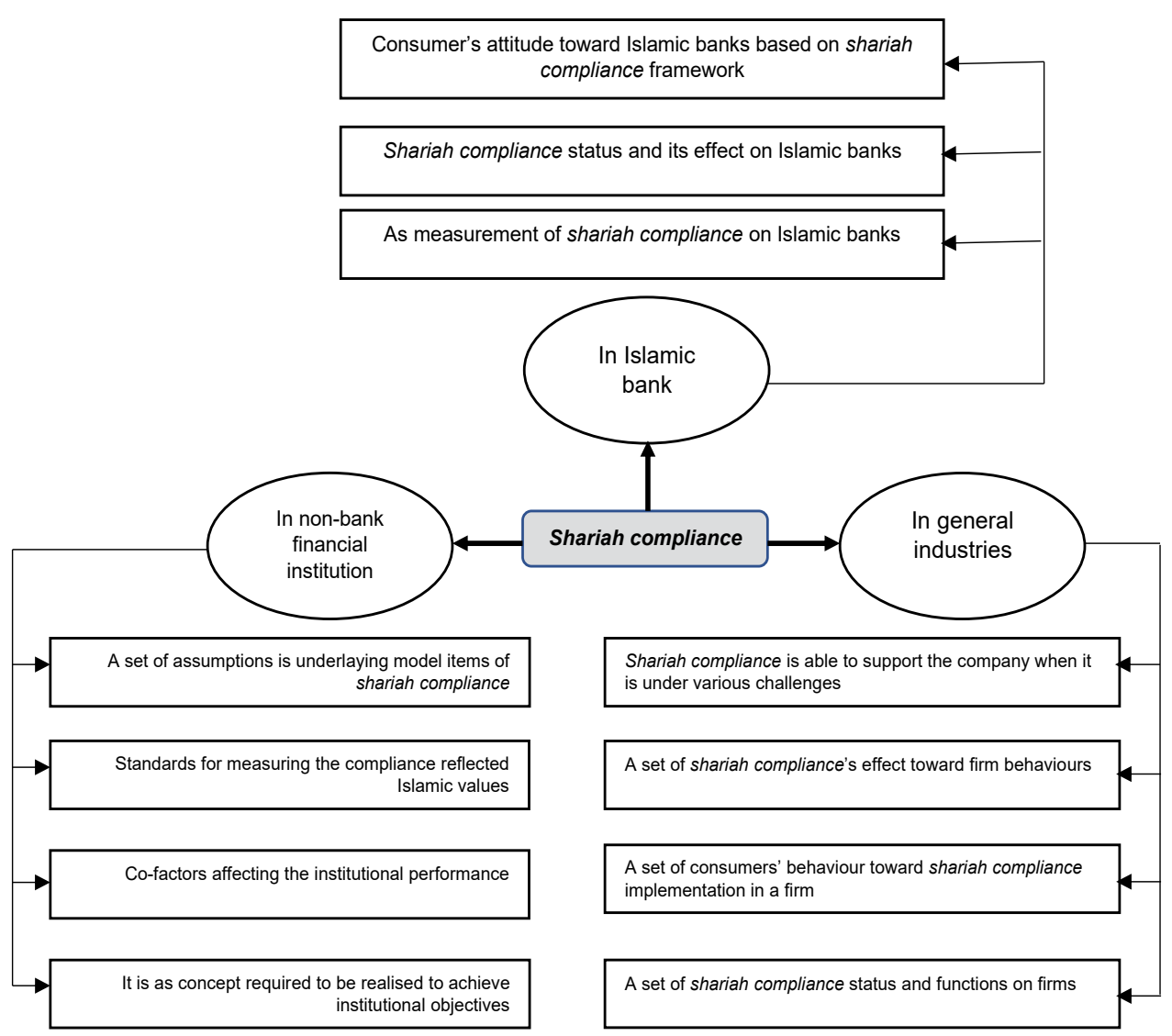

Figure 5. General classification of issues in shariah compliance

conducted a study on the status of shariah compliance in Malaysia as a strict legal requirement. Islamic Financial Institutions (IFIs) in this country are under the monitoring of internal Shariah Committees (SCs) to ensure the implementation of shariah principles. Suzuki and Miah (2021) also showed that implementing this compliance concept in Islamic banks was the foundation for benchmarking. These two studies are in line with others, which revealed that the status of shariah compliance is a legal requirement for product and institutional restructuring of Islamic banks (Abdul Rahman \& Masngut, 2014; Ahmed \& Farooq, 2018; Anwer et al., 2020; Ullah, 2014). However, the functions are different between Islamic and conventional banks, and

(iii) Shariah compliance as a measurement. In this regard, Rosly et al. (2017) discovered that it has positively significant impacts on the performance of Islamic banking. Empirically, it positively influences these banks' performance everywhere (Alaudin et al., 2015; Ali \& Hassan, 2020; Julia et al., 2016; Rafay \& Farid, 2018). Therefore, shariah values simultaneously guarantee protection for the banking industry and its customers (Hardivizon et al., 2016; Hassan et 
al., 2018; Sholihin, 2020). Consequently, this protection automatically increases customer confidence, loyalty and satisfaction towards Islamic banks.

The second classification relates to non-bank financial institutions, where 23 articles were identified. For these institutions, shariah compliance was studied in three topics as follows:

(i) as a set of assumptions underlying the items of the compliance model. In this case, Alkhan and Hassan (2020) affirmed it was the foundation of how ideally takaful operates. Hazny et al. (2020) offered a mathematical concept of shariah compliance in the capital asset pricing model (CAPM). Prior to that, Hazny et al. (2012) successfully introduced a model based on Markowitz's mean-variance analysis using the shariah compliance framework. The results indicated that CAPM could measure the relationship between risk and return of Islamic finance. Moreover, research teams in this category believe that shariah compliance serves as a framework for restructuring financial products and institutions (Laldin \& Furqani, 2018). This paradigm can also be a source of assumptions from various models in the Islamic economy (Hanif, 2018, 2019). Therefore, it is a normative structure for restructuring Islamic financial products or institutions in both banks and non-bank institutions,

(ii) as a standard measure of compliance based on shariah values. The articles that can be grouped into this category include Ahmed et al. (2019), Kasim (2012) and Mukhlisin (2020). Mukhlisin (2020) assumed that an Islamic financial industry could be categorised as a shariah entity. This was obtained from financial reports based on the norm and ethics of Islam, and

(iii) shariah compliance in non-bank financial institutions also functions as cofactors that influence their performance. For example, Tajuddin et al. (2019) successfully showed that shariah compliance positively influenced the initial public offerings (IPOs) in Malaysia. Meanwhile, Can (2020) showed that it effectively improved financial reporting quality. These two studies were supported by the results of Islamic economics scholars, such as Boudt et al. (2019), Mustapha et al. (2019) and Zhang et al. (2019). They believed that it can be theoretically used as a variable with a significant effect on the performance of non-bank institutions, and can be verified empirically.

The third classification of the existing literature is "in general industries" which can be classified into four topics as follows:

(i) shariah compliance plays a supporting role under various challenges (Cheong, 2021; Sharif et al., 2020). Cheong (2021) identified the challenges companies faced in situations with risk uncertainty. In this situation, the paradigm helps companies to minimise risks through idiosyncratic risk and strengthen resilience,

(ii) classification refers to a set of shariah compliance effects towards firm behaviours (Abdul Hasim et al., 2019; Ahmad et al., 2020; Ahmed \& Farooq, 2018; Akguc \& Al Rahahleh, 2018; Akinsomi et al., 2014; Azmat et al., 2016; Balli, De Bruin, et al., 2020; Dali Nuradli Ridzwan Shah Bin et al., 2008; Farooq 
\& Alahkam, 2016; Hussain et al., 2020; Pepis \& de Jong, 2019; Rahayati et al., 2020; Satt et al., 2020; Sulaiman et al., 2020),

(iii) a set of consumers' behaviour towards the compliance concept in a firm. Htay and Salman (2013) emphasised that shariah compliance in a company functions as a value provider, where Islamic financial institutions should consider shariah values. The authors offered an evaluation instrument as a measuring tool for companies to evaluate the consistency of the values. Based on this, the status of shariah compliance in a company is a framework for its behaviour (Abdul-Rahim et al., 2019). This framework is a prerequisite for the formation of an image or benchmarking as a company that is consistent with shariah values, and

(iv) a set of shariah compliance status and functions on firms. Laldin and Furqani (2016) stated that it is positioned as an ethical and legal foundation for restructuring Islamic banking products and institutions. Campisi et al. (2018) viewed it as an indicator of the Islamic banks' upholding of Islamic identity.

In summary, various related articles concluded that shariah compliance for the financial or economic industries serves as an ethical and legal framework with limitations (Laldin \& Furqani, 2016). With this concept, Islamic banks are encouraged to invest and minimise the replication of the conventional financial system. Therefore, Islamic financial products and institutions look not only distinct but are substantially different from conventional banks. In this regard, the substance of shariah compliance is interpreted as the core of Islamic banks.

\section{Discussion}

This study has resulted in a notion that the study of shariah compliance is still limited to the context of institutions and oriented towards evaluating the commitment of Islamic financial institutions as well as other economic industries towards shariah values. In this context, the evaluation can be offered as the foundation for determining the development direction of shariah compliance studies. During its development, the emergence of shariah compliance is a consequence of the ambition of Islamic finance to replicate the entire conventional financial structure. Based on this paradigm, the concept also becomes a standard for the Shariah Board Supervisory to evaluate the Islamic banks - are the banks run correctly per Islamic values and guidelines (Laldin \& Furqani, 2016)? This tendency cannot be concluded as wrong. However, the effort is insufficient for reducing the Islamisation process of banks based on a legalistic approach per se (Ahmed \& Farooq, 2018; Laldin \& Furqani, 2016). It requires the shariah compliance paradigm that boils down to maqasid shariah.

The development of shariah compliance based on the maqasid shariah paradigm is undoubtedly different from the proposal by Laldin and Furqani (2016). Both gave an idea that innovation in Islamic finance should be built within a solid Islamic financial framework. They believed that replicating the entire conventional product structure within the shariah compliance framework is not the primary and legitimate goal in the effort to build a genuinely Islamic bank. In this regard, the innovation of Islamic 
finance should adopt a systemic approach to develop a new financial Islamic bank. It should also aim to eliminate the shortcomings of the conventional financial system and create an Islamic worldview or vision in the financial sector to achieve Islamic economic goals. Furthermore, the framework is philosophically rooted in the spirit of maqasid shariah (Islamic objective) as the foundation for developing an Islamic economic system (Hidayat et al., 2019; Oktaviana \& Pimada, 2019). Without realising it, the current development in a shariah-compliant paradigm has led to the improvement of maqasid shariah-based finance. It also succeeded in introducing the maqasid shariah index, which helps to evaluate the commitment of Islamic banks to the Islamic worldview (Mukminin, 2019). However, this development did not reveal the fundamental character of these banks as a profitability-oriented business institution.

Several fundamental criticisms can be directed to the shariah compliance paradigm and maqasid shariah when used as a framework for Islamising financial institutions. First, shariah compliance as a paradigm concentrates on product issues and institutional structuring (Djibrilla et al., 2017; Suzuki \& Miah, 2021). Meanwhile, Islamic economists generally use maqasid shariah to evaluate the commitment of Islamic banks and financial institutions to shariah values, especially in the context of maintaining maslahah with healthy financial performance, i.e., the financial industry's commitment to social needs through a corporate social responsibility scheme (Laldin \& Furqani, 2013). Concretely, Laldin and Furqani (2013) offered a set of shariah objectives for Islamic banks, i.e., wealth circulation, fair and transparent financial practices, as well as justice at the micro-macro level. To achieve this goal, shariah introduced several instruments (wasa'il), such as financial contracts based on Islamic values and standards as well as institutionalised social responsibility.

Maqasid shariah as a set of shariah objectives that becomes a standard and guidelines rooted in revelation (wahy) is applied to solve problems and serve as a guide for humans' lives (Dusuki \& Abdullah, 2007; Ibrahim et al., 2019; Laldin \& Furqani, 2013). It supports the development of Islamic banks within the shariah-compliant and maqasid shariah frameworks simultaneously. Therefore, maqasid shariah should evaluate the commitment and implementation of the Islamic value system in these banks. However, both paradigms do not question the implications of the financial institutions' excessive ambition and orientation towards profitability. As a response, it is necessary to develop an instrument for evaluating the implications of excessive rentseeking in the banks. This instrument is known as the "exploitation index." It measures the impact of a product restructuring, management and rent-seeking behaviour of Islamic financial institutions towards the exploited experience that customers feel when transacting with them.

Furthermore, this instrument is also an evaluation technique for psychological effects experienced by customers during transactions with shariah banks. Its concept measures a set dimension as follows: (i) experience as a customer, i.e., the psychological impact experienced when signing a contract, pay obligations or inability to fulfill them, (ii) the economic impact as a consequence of being a customer, with all the obligations that should be fulfilled, especially when receiving financing from Islamic banks. The paradigm refers to both shariah compliance and maqasid shariah, which is maslahah oriented and protects customer rights per Islamic guidance (Abubakar, 2016; 
Mohammed, 2013; Zatadini \& Syamsuri, 2018). In addition, the prohibition on the practice of ribawi (usury or interest) in conventional banks correlates with the primary objective of bank Islamisation (Abdel-Baki \& Leone Sciabolazza, 2014; Hardivizon \& Sholihin, 2021; Nienhaus, 2011). Briefly, there was no exploitation of customers through debit and credit schemes from banks. Therefore, in the development of Islamic banks, the paradigm should be linked to the exploitation index. This helps to evaluate the commitment of shariah banks to Islamic values and measure the direct impact of commitment on their customers and other related financial institutions.

In addition, encouraging the transformation of shariah compliance to maqasid shariah is part of the mission for financial industry Islamisation by making Tawhid (monotheism) the centre of the framework and values behind the Islamisation (Choudhury, 2019a). Choudhury (2020) stated that Tawhid is "the essential law of everything." Its applications are currently in the lives of Muslims and are being awaited or pursued. Although efforts to implement maqasid shariah have taken place, they are not enough to relate it with the "Islamic monotheistic worldview". The argument put forward by Choudhury (2019a; 2020) regarding the effort to complete maqasid shariah with the tawhid-paradigm, lies in the philosophical assumption that Islamisation of the financial industry is not enough to make the entire system and their management linear or in line with shariah values, such as abolishing usury. However, the effort should be holistic and organic (Choudhury, 2019b, 2020). It should be realised that the belief in Allah (Tawhid) will ethically affect human behaviour (Choudhury, 2005). Therefore, for the development of the Islamic finance industry to be more humane, it cannot be done partially and fragmentedly, by only prioritising the shariah compliance aspects or being oriented to maqasid shariah.

Nevertheless, it should be accompanied by efforts to build "awareness of monotheism." Therefore, the development of this finance industry should be holistic and organically based on the belief in Allah and true faith. In short, these three paradigms (shariah compliance; maqasid shariah, and tawhid paradigm, as well as preventing exploitation) encourage the systematic Islamisation of conventional banks in a human-oriented approach. Therefore, Islamisation can run in the spirit of "dafu al-mafāsid aqdam min tajlib al-masālih," and preventing exploitation takes precedence over realising maslahah.

\section{Conclusion}

The shariah compliance paradigm has attracted the interest of Islamic economists to design various instruments, models and concepts to evaluate the product structuring and management process of Islamic financial institutions. Various literature was written to explain the issues. Consequently, the literature had a broad impact on developing studies on shariah compliance, either as a paradigm or framework or just a research issue. Various authors were involved with a broader and interdisciplinary perspective. Empirically, some trends were obtained from the bibliometric analysis on 233 articles in reputable international journals indexed by Scopus. The issue of shariah compliance is concentrated in Islamic financial institutions and companies. It was indicated by the author's highest contribution, which concentrated on the study of shariah compliance in 
these banks. However, several articles attempted to re-examine the paradigm critically and ended up offering its integration with maqasid shariah.

As for the application of systematic literature review to 82 articles, there were at least three classifications of studies related to shariah compliance. First, the issue of shariah compliance was studied in Islamic banks. Topics that appeared in this classification include (i) consumers' attitude towards Islamic banks based on the paradigm framework, (ii) shariah compliance status and its effect towards Islamic banks, (iii) measuring shariah compliance of Islamic banks. Second, shariah compliance was studied in relation to non-bank financial institutions. Third, the issues concerning companies as well as other industries such as hotels and halal tourism, were discussed.

Although the development of the literature was shariah compliance, it was very significant and had a broad impact. However, the paradigm cannot be considered a complete conceptual framework or instrument to evaluate financial institutions' compliance in innovating and replicating conventional financial structures. Therefore, besides the need to be equipped with the maqasid shariah paradigm, it is also necessary to develop the exploitation index to prevent harmful or exploitative implications of the banks' natural character as an industry oriented towards capital gains and profitability. In addition, Islamisation of banks in a holistic effort requires the consideration of tawhid (belief in one God, namely, Allah). However, this article did not thoroughly discuss the scale of exploitation index measurement with accompanying indicators. It is recommended as a topic for further study and can be carried out by scholars or other Islamic economists in the future.

\section{References}

Abbas, S.Z.M., Rahman, R.A., \& Mahenthiran, S. (2009, April 21). Ultimate ownership and performance of Islamic financial institutions in Malaysia. Paper presented at the Asian Finance Association Conference, July, Brisbane, Australia, 1-25. https://papers.ssrn.com/ sol3/papers.cfm?abstract_id $=1392833$

Abdel-Baki, M., \& Leone Sciabolazza, V. (2014). A consensus-based corporate governance paradigm for Islamic banks. Qualitative Research in Financial Markets, 6(1), 93-108. https:// doi.org/10.1108/QRFM-01-2013-0002

Abdul-Rahim, R., A. Wahab, A., \& Yusoff, N.A. (2019). Impact of shariah-compliant status on firms' decision to practice forex hedging. Journal of Islamic Accounting and Business Research, 10(5), 756-769. https://doi.org/10.1108/JIABR-06-2016-0076

Abdul Hasim, H.F., Mohd Ariffin, N., \& Zakaria, M.Z. (2019). Review on measurement techniques and technologies to propose new rating scale measurement for shariah compliant hotel industry in Malaysia. Indonesian Journal of Electrical Engineering and Computer Science, 16(2), 685-691. https://doi.org/10.11591/ijeecs.v16.i2.pp685-691

Abdul Rahman, R., \& Masngut, M.Y. (2014). The use of "CAMELS" in detecting financial distress of Islamic banks in Malaysia. Journal of Applied Business Research, 30(2), 445-452. https://doi. org/10.19030/jabr.v30i2.8416

Abubakar, Y.S. (2016). Corporate social responsibility of Islamic financial institutions: A look from the Maqasid Al-Shariah (Purpose of Shariah) approach. Business and Economics Journal, 7(4), 1-4. https://doi.org/10.4172/2151-6219.1000255

Ahmad, F., Seyyed, F.J., \& Ashfaq, H. (2020). Managing a shariah-compliant capital protected fund through turbulent times. Asian Journal of Management Cases, 17(1_suppl), S32-S41. https:// doi.org/10.1177/0972820119884397 
Ahmed, H, Tajul Ariffin, F.A., Karbhari, Y., \& Shafii, Z. (2019). Diverse accounting standards on disclosures of Islamic financial transactions: Prospects and challenges of narrowing gaps. Accounting, Auditing and Accountability Journal, 32(3), 866-896. https://doi.org/10.1108/ AAAJ-10-2015-2266

Ahmed, N., \& Farooq, O. (2018). Does the degree of Shari'ah compliance affect the volatility? Evidence from the MENA region. Research in International Business and Finance, 45(4), 150-157. https://doi.org/10.1016/j.ribaf.2017.07.143

Akguc, S., \& Al Rahahleh, N. (2018). Effect of shariah compliance on operating performance: Evidence from GCC countries. Emerging Markets Finance and Trade, 54(12), 2874-2896. https://doi.org/10.1080/1540496X.2018.1425991

Akinsomi, O., Ong, S.E., Ibrahim, M.F., \& Newell, G. (2014). The idiosyncratic risks of a Shariah compliant REIT investor. Journal of Property Research, 31(3), 211-243. https://doi.org/10.108 $0 / 09599916.2013 .841276$

Alam, N., \& Rajjaque, M.S. (2010). Shariah-compliant equities: Empirical evaluation of performance in the European market during credit crunch. Journal of Financial Services Marketing, 15(3), 228-240. https://doi.org/10.1057/fsm.2010.19

Alaudin, A., Shantapriyan, P., \& Adler, R.W. (2015). Beliefs and accountability in an Islamic bank. Corporate Ownership \& Control, 12(4), 80-90. https://doi.org/10.22495/cocv12i4p6

Alharbi, A. (2015). Development of the Islamic banking system. Journal of Islamic Banking and Finance, 3(1), 12-25. https://doi.org/10.15640/jibf.v3n1a2

Ali, M.M., \& Hassan, R. (2020). Survey on Sharīah non-compliant events in Islamic banks in the practice of tawarruq financing in Malaysia. ISRA International Journal of Islamic Finance, 12(2), 151-169. https://doi.org/10.1108/IJIF-07-2018-0075

Alkhan, A.M., \& Hassan, M.K. (2020). Takaful operators: Analysing segregated accounts between operator/participants. Journal of Islamic Accounting and Business Research, 11(9), 16491664. https://doi.org/10.1108/JIABR-01-2020-0005

Amaroh, S., \& Masturin, M. (2018). The determinants of maqasid shariah based performance of Islamic banks in Indonesia. IQTISHADIA, 11(2), 354-370. https://doi.org/10.21043/iqtishadia. v11i2.3961

Amin, H., \& Hamid, M.R.A. (2018). Patronage factors of tawarruq home financing in Malaysia. International Journal of Business and Society, 19(3), 660-677.

Anwer, Z., Khan, S., \& Abu Bakar, M. (2020). Sharīah-compliant central banking practices: Lessons from Muslim countries' experience. ISRA International Journal of Islamic Finance, 12(1), 7-26. https://doi.org/10.1108/IJIF-01-2019-0007

Aria, M., \& Cuccurullo, C. (2017). bibliometrix: An R-tool for comprehensive science mapping analysis. Journal of Informetrics, 11(4), 959-975. https://doi.org/10.1016/j.joi.2017.08.007

Arliza, W., Zainal, W., Kasim, N., Zakaria, N.B., Mohamed, N., \& Penawar, B. (2016). Disputes and resemblance: Comparative analysis of shariah advisory committee methodology and international indices. Management \& Accounting Review (MAR), 15(2), 1-10. https://doi. org $/ 10.24191 /$ mar.v15i2.584

Ayedh, A.M.A., Shaharuddin, A., \& Kamaruddin, M.I.H. (2019). Shariah screening methodology: Does it 'really' shariah compliance? IQTISHADIA, 12(2), 144. https://doi.org/10.21043/ iqtishadia.v12i2.5573

Azam, M., Akhtar, J., Ali, S.A., \& Mohy-Ud-Din, K. (2019). The moderating role of Shariah compliance on the relationship between firm profitability and CSR activities: An ethical obligation. International Journal of Ethics and Systems, 35(4), 709-724. https://doi.org/10.1108/IJOES-02-2019-0039

Azmat, S., Jalil, M.N., Skully, M., \& Brown, K. (2016). Investor's choice of Shariah compliant 'replicas' and original Islamic instruments. Journal of Economic Behavior and Organization, 132, 4-22. https://doi.org/10.1016/j.jebo.2016.07.018 
Baber, H. (2019). Relevance of e-SERVQUAL for determining the quality of FinTech services. International Journal of Electronic Finance, 9(4), 257-267. https://doi.org/10.1504/IJEF. 2019.104070

Balli, F., Chowdhury, M.I.H., \& de Bruin, A. (2020). Transition to Islamic equities: Systematic risk and Shari'ah compliance. Global Finance Journal, Article 100552. https://doi.org/10.1016/j. gfj.2020.100552

Balli, F., De Bruin, A., Balli, H.O., \& Karimov, J. (2020). Corporate net income and payout smoothing under Shari'ah compliance. Pacific Basin Finance Journal, 60, Article 101265. https://doi. org/10.1016/j.pacfin.2020.101265

Bornmann, L. (2020). How can citation impact in bibliometrics be normalized? A new approach combining citing-side normalization and citation percentiles. Quantitative Science Studies, 1(4), 1553-1569. https://doi.org/10.1162/qss_a_00089

Boudt, K., Raza, M.W., \& Wauters, M. (2019). Evaluating the Shariah-compliance of equity portfolios: The weighting method matters. International Review of Financial Analysis, 63, 406-417. https://doi.org/10.1016/j.irfa.2017.12.003

Campisi, D., Gitto, S., \& Morea, D. (2018). Shari'ah-compliant finance: A possible novel paradigm for green economy investments in Italy. Sustainability, 10. Article 113915. https://doi.org/ $10.3390 /$ su10113915

Can, G. (2020). Does Sharia compliance affect the financial reporting quality? An evidence from Muslim majority countries. International Journal of Islamic and Middle Eastern Finance and Management, 14(1), 16-33. https://doi.org/10.1108/IMEFM-04-2019-0149

Cheong, C.W.H. (2021). Risk, resilience, and Shariah-compliance. Research in International Business and Finance, 55, Article 101313. https://doi.org/10.1016/j.ribaf.2020.101313

Choudhury, M.A. (2005). The Islamic world-system: A study in polity-market interaction. Routledge. https://doi.org/10.4324/9780203987315

Choudhury, M.A. (2019a). Meta-science of tawhid: A theory of oneness. Palgrave Macmillan.

Choudhury, M.A. (2019b). The tawhidi methodological worldview: A transdisciplinary study of Islamic economics. Springer. https://doi.org/10.1007/978-981-13-6585-0_2

Choudhury, M.A. (2020). Tawhid and shari'ah: A transdisciplinary methodological enquiry. Palgrave Macmillan.

Dali Nuradli Ridzwan Shah Bin, M., Hamdi Hakeim, M., \& Hamid Suhaila, A. (2008). Performance of Shariah compliance companies in the plantation industry. International Journal of Islamic and Middle Eastern Finance and Management, 1(2), 166-178. https://doi.org/ $10.1108 / 17538390810881008$

Daud, W. (2017). Takaful rules and regulations for ASEAN countries: Takaful player perspectives. In Proceedings of the 30th International Business Information Management Association Conference, IBIMA 2017 - Vision 2020: Sustainable Economic development, Innovation Management, and Global Growth (Vol. 2017, pp. 2363-2369).

Djibrilla, M.M., Buang, A.H., \& Olayemi, A.A.M. (2017). The challenges of shariah compliance in the Islamic banking practices: Whether Ibn-Al Qayyim's principles of muamalat be the panacea? The Journal of Muamalat and Islamic Finance Research, 14(1) 73-85. https://jmifr. usim.edu.my/index.php/jmifr/article/view/15

Dusuki, A.W., \& Abdullah, N.I. (2007). Maqasid al-Shari'ah, maslahah, and corporate social responsibility. American Journal of Islamic Social Sciences, 24(1), 25-45. https://doi.org/10.35632/ ajiss.v24i1.415

Ehsan Wahla, A., Hasan, H., \& Bhatti, M.I. (2018). Measures of customers' perception of car ljarah financing. Journal of Islamic Accounting and Business Research, 9(1), 2-16. https://doi. org/10.1108/JIABR-10-2015-0051

El-Gohary, H. (2016). Halal tourism, is it really Halal? Tourism Management Perspectives, 19(Part B), 124-130. https://doi.org/10.1016/j.tmp.2015.12.013 
Farooq, O., \& Alahkam, A. (2016). Performance of shariah-compliant firms and non-shariahcompliant firms in the MENA region: Which is better? Journal of Islamic Accounting and Business Research, 7(4), 268-281. https://doi.org/10.1108/JIABR-10-2013-0039

Fisch, C., \& Block, J. (2018). Six tips for your (systematic) literature review in business and management research. Management Review Quarterly, 68(2), 103-106. https://doi.org/10.1007/ s11301-018-0142-x

Guyot, A. (2011). Efficiency and dynamics of Islamic investment: Evidence of geopolitical effects on Dow Jones Islamic Market indexes. Emerging Markets Finance and Trade, 47(6), 24-45. https://doi.org/10.2753/REE1540-496X470602

Hanif, M. (2018). Sharīah-compliance ratings of the Islamic financial services industry: A quantitative approach. ISRA International Journal of Islamic Finance, 10(2), 162-184. https:// doi.org/10.1108/IJIF-10-2017-0038

Hanif, M. (2019). Shariah screening process of capital markets: An evaluation of methodologies. Journal of King Abdulaziz University, Islamic Economics, 32(1), 23-42. https://doi. org/10.4197/Islec.32-1.2

Haque, A., Ahmed, K., \& Jahan, S.I. (2010). Shariah observation: Advertising practices of Bank Muamalat in Malaysia. Journal of Islamic Marketing, 1(1), 70-77. https://doi. org/10.1108/17590831011026240

Hardivizon, H., \& Sholihin, M. (2021). Hybrid rationality behind customers' choices of the Islamic banks: An experience of Bengkulu, Indonesia. Journal of Islamic Thought and Civilization, 11(1), 175-200. https://doi.org/10.32350/jitc.111.10

Hardivizon, H., Sholihin, M., \& Anrial, A. (2016). Relasi agama dan pilihan nasabah: Grounded theory dan reposisi agama pada pilihan nasabah bank di Provinsi Bengkulu. Turast: Jurnal Penelitian dan Pengabdian, 4(1), 1-19. https://doi.org/10.15548/turast.v4i1.306

Hassan, R., Salman, S.A., \& Yusoff, A. (2018). Idealism versus realism: Performance of Islamic financial institutions in the light of Maqasid-Al Shari'ah. Proceedings of the 32nd International Business Information Management Association Conference, IBIMA 2018 - Vision 2020: Sustainable Economic Development and Application of Innovation Management from Regional expansion to Global Growth (pp. 7011-7014). International Business Information Management Association, IBIMA. https://www.scopus.com/inward/record.uri?eid=2-s2.085063044320\&partnerID $=40 \& m d 5=60 f a b e b 75 d 1 d 047$ bec9c183f3dce2c7b

Hazny, M.H., Hashim, H.M., \& Yusof, A.Y. (2012). Revisiting Markowitz's mean variance analysis: A review from shariah perspective. In 2012 International Conference on Statistics in Science, Business and Engineering (ICSSBE) (pp. 1-6). Institute of Electrical and Electronics Engineers (IEEE). https://doi.org/10.1109/ICSSBE.2012.6396577

Hazny, M.H., Hasim, H.M., \& Yusof, A.Y. (2020). Mathematical modelling of a shariah-compliant capital asset pricing model. Journal of Islamic Accounting and Business Research, 11(1), 90-109. https://doi.org/10.1108/JIABR-07-2016-0083

Heradhyaksa, B., \& Markom, R. (2018). Jurisdiction of Sharia Supervisory Board in Indonesian takaful industry. IOP Conference Series: Earth and Environmental Science, 175(1). https://doi. org/10.1088/1755-1315/175/1/012177

Hidayat, R., Oktaviani, Y., \& Aminudin, A. (2019). Financial performance of Islamic banking In Indonesia with maqasid shariah approach. Manajemen Bisnis, 9(1), 85-97. https://doi. org/10.22219/jmb.v9i1.9442

Htay, S.N.N., \& Salman, S.A. (2013). Balanced score card approach for better Shari'ah corporate governance. American Journal of Applied Sciences, 10(12), 1553-1557. https://doi.org/ 10.3844/ajassp.2013.1553.1557

Hussain, H.I., Ali, M., Hassan, M.K., \& El-Khatib, R. (2020). Asymmetric capital structure speed of adjustment, equity mispricing and Shari'ah compliance of Malaysian firms. International 
Review of Economics \& Finance. Advance online publication. https://doi.org/10.1016/j. iref.2020.10.017

Ibrahim, A.H., Rahman, N.N.A., Saifuddeen, S.M., \& Baharuddin, M. (2019). Maqasid al-Shariah based Islamic bioethics: A comprehensive approach. Journal of Bioethical Inquiry, 16(3), 333-345. https://doi.org/10.1007/s11673-019-09902-8

Indarti, N., Lukito-budi, A.S., \& Islam, A.M. (2020). A systematic review of halal supply chain research: To where shall we go? Journal of Islamic Marketing. Advance online publication. https://doi.org/10.1108/JIMA-05-2020-0161

Ingale, K.K., \& Paluri, R.A. (2020). Financial literacy and financial behaviour: A bibliometric analysis. Review of Behavioral Finance. Advance online publication. https://doi.org/10.1108/ RBF-06-2020-0141

Jalil, A., \& Osman, S. (2019). Development of shariah compliance and governance regulations within the Malaysian Islamic banking industry: An analysis. Paper presented at the International Islamic Economic System Conference, November, 1-12. file://C:/Users/User/ Downloads/iECONS2019DevelopmentofShariahComplianceandGovernanceRegulations.pdf

Jobst, A.A. (2009). Islamic securitisation: An ethical remedy to incentive problems? International Journal of Monetary Economics and Finance, 2(3/4), 348-365. https://doi.org/10.1504/ IJMEF.2009.029068

Johan, Z.J., Hussain, M.Z., Mohd, R., \& Kamaruddin, B.H. (2020). Muslims and non-Muslims intention to hold Shariah-compliant credit cards: A SmartPLS approach. Journal of Islamic Marketing. Advance online publication. https://doi.org/10.1108/JIMA-12-2019-0270

Julia, T., Rahman, M.P., \& Kassim, S. (2016). Shariah compliance of green banking policy in Bangladesh. Humanomics, 32(4), 390-404. https://doi.org/10.1108/H-02-2016-0015

Kaakeh, A., Hassan, M.K., \& Van Hemmen Almazor, S.F. (2019). Factors affecting customers' attitude towards Islamic banking in UAE. International Journal of Emerging Markets, 14(4), 668-688. https://doi.org/10.1108/IJOEM-11-2017-0502

Kahf, M., \& Al-Saudi, H. (2016). Special purpose vehicles and corporate Sukūk: How true is "True Sale"? Journal of King Abdulaziz University, Islamic Economics, 29(2), 3-21. https://doi. org/10.4197/Islec.29-2.1

Kammer, A., Norat, M., Pinon, M., Prasad, A., Towe, C.M., \& Zeidane, Z. (2015). Islamic finance: Opportunities, challenges, and policy options. IMF Staff Discussion Notes (Vol. 2015, Issue 5). https://doi.org/10.5089/9781498325035.006

Kasim, N.A.A. (2012). Disclosure of Shariah compliance by Malaysian takaful companies. Journal of Islamic Accounting and Business Research, 3(1), 20-38. https://doi.org/10.1108/ 17590811211216041

Kasim, N. binti, Salman, S.A., \& Htay, S.N.N. (2016). Achieving effective Waqf management through compliance with Shari'ah Governance Practices. In Proceedings of the 27th International Business Information Management Association Conference - Innovation Management and Education Excellence Vision 2020 (pp. 1326-1329). International Business Information Management Association, IBIMA.

Kraus, S., Li, H., Kang, Q., Westhead, P., \& Tiberius, V. (2020). The sharing economy: A bibliometric analysis of the state-of-the-art. International Journal of Entrepreneurial Behavior \& Research, 26(8), 1769-1786. https://doi.org/10.1108/IJEBR-06-2020-0438

Kusuma, H. (2019). Determinants of zakah disclosure level: Evidence For Indonesia. International Journal of Islamic Economics and Finance Studies, 5(3), 16-27. https://doi.org/10.25272/ ijisef.583662

Laldin, M.A., \& Furqani, H. (2013). Developing Islamic finance in the framework of maqasid alShari'ah: Understanding the ends (maqasid) and the means (wasa'il). International Journal of Islamic and Middle Eastern Finance and Management, 6(4), 278-289. https://doi.org/ 10.1108/IMEFM-05-2013-0057 
Laldin, M.A., \& Furqani, H. (2016). Innovation versus replication: Some notes on the approaches in defining shariah compliance in Islamic finance. Al-Jami'ah: Journal of Islamic Studies, 54(2), 249-272. https://doi.org/10.14421/ajis.2016.542.249-272

Laldin, M.A., \& Furqani, H. (2018). Islamic Financial Services Act (IFSA) 2013 and the Shari'ahcompliance requirement of the Islamic finance industry in Malaysia. ISRA International Journal of Islamic Finance, 10(1), 94-101. https://doi.org/10.1108/IJIF-12-2017-0052

Majid, N.H.A., Denan, Z., Abdullah, F.H., \& Noor, M.S.M. (2015). Shariah compliance hospitality building design: A Malay Muslim oriented architecture. Procedia - Social and Behavoiral Sciences, 201, 136-145. https://doi.org/10.1016/j.sbspro.2015.08.159

Mansoor, M., Ellahi, N., Hassan, A., Malik, Q.A., Waheed, A., \& Ullah, N. (2020). Corporate governance, shariah governance, and credit rating: A cross-country analysis from Asian Islamic banks. Journal of Open Innovation: Technology, Market, and Complexity, 6(4), 1-15. https:// doi.org/10.3390/joitmc6040170

Merdad, H., Hassan, M.K., \& Khawaja, M. (2016). Does faith matter in mutual funds investing? Evidence from Saudi Arabia. Emerging Markets Finance and Trade, 52(4), 938-960. https:// doi.org/10.1080/1540496X.2015.1025655

Miles, M.B., \& Huberman, A.M. (1994). Qualitative data analysis: An expanded sourcebook. SAGE Publications.

Miskam, S., Yaakub, N.I., \& Hamid, M.A. (2017). Shari'ah governance in Islamic capital market: Towards achieving Maqasid Shari'ah. Advanced Science Letters, 23(1), 169-172. https://doi. org/10.1166/asl.2017.7215

Mohammed, J.A. (2013). Business precepts of Islam: The lawful and unlawful business transactions according to shariah. In C. Luetge (Ed.), Handbook of the philosophical foundations of business ethics. Springer. https://doi.org/10.1007/978-94-007-1494-6

Muhamad, R. (2011). Shariah compliance process and corporate governance in Islamic banking institutions (IBIs): A proposed model. Asian Journal of Accounting Perspectives, 4(1), 36-48. https://doi.org/10.22452/AJAP.vol4no1.3

Mukhlisin, M. (2020). Level of Maqāsid ul-Shari'āh's in financial reporting standards for Islamic financial institutions. Journal of Islamic Accounting and Business Research, 12(1), 60-77. https://doi.org/10.1108/JIABR-03-2020-0090

Mukminin, K. (2019). Profit maximization in Islamic banking: An assemblage of maqasid shariah conception. European Journal of Islamic Finance, 12, 1-10. https://doi.org/10.13135/2421$2172 / 2856$

Mustapha, Z., Kunhibava, S., \& Muneeza, A. (2019). Court referral and Nigeria's Financial Regulation Advisory Council of Experts (FRACE). ISRA International Journal of Islamic Finance, 11(2), 206-225. https://doi.org/10.1108/IJIF-11-2018-0126

Nienhaus, V. (2011). Islamic finance ethics and Shari'ah law in the aftermath of the crisis: Concept and practice of Shari'ah compliant finance. Ethical Perspectives, 18(4), 591-623. https://doi. org/10.2143/EP.18.4.2141849

Nomran, N.M., \& Haron, R. (2019). A systematic literature review on Shari'ah governance mechanism and firm performance in Islamic banking. Islamic Economic Studies, 27(2), 13191616. https://doi.org/10.1108/IES-06-2019-0013

Noor, R.M., Rashid, \& Mastuki, N. (2011). Zakat and tax reporting: Disclosures practices of Shariah compliance companies. 2011 IEEE Colloquium on Humanities, Science and Engineering, 877882. https://doi.org/10.1109/CHUSER.2011.6163862

Norbayusri Baharudin, M., Mohamad, M., \& Karim, F. (2020). Drug-abuse inmates maqasid shariah quality of life: A conceptual paper. Humanities \& Social Sciences Reviews, 8(3), 12851294. https://doi.org/10.18510/hssr.2020.83131

Nugraha, E., Nugroho, L., Lindra, C., \& Sukiati, W. (2020). Maqashid sharia implementation in Indonesia and Bahrain. Etikonomi: Jurnal Ekonomi, 19(1), 155-168. https://doi.org/10.15408/ etk.v19i1.14655 
Oktaviana, U.K., \& Pimada, L.M. (2019). Integrated Maqasid Sharia Index: Indonesia Islamic banks performance. Proceedings of the 2018 International Conference on Islamic Economics and Business (ICONIES 2018), (266-271). https://doi.org/10.2991/iconies-18.2019.52

Paranque, B., \& Erragragui, E. (2016). Islamic investment versus socially responsible investment: Lessons from comparison. In Critical studies on corporate responsibility, governance and sustainability (Vol. 10, pp. 355-383). Emerald Group Publishing Ltd. https://doi.org/10.1108/ S2043-905920160000010034

Pepis, S., \& de Jong, P. (2019). Effects of Shariah-compliant business practices on long-term financial performance. Pacific Basin Finance Journal, 53, 254-267. https://doi.org/10.1016/j. pacfin.2018.11.002

Rafay, A., \& Farid, S. (2018). Shariah Supervisory Board Report (SSBR) in Islamic banks: An experimental study of investors' perception and behavior. International Journal of Islamic and Middle Eastern Finance and Management, 11(2), 274-296. https://doi.org/10.1108/ IMEFM-07-2017-0180

Rahayati, A., Roshima, S., Syahiza, A., Nadirah, A.M.F., \& Shahariza, A.H.N. (2020). The influence of dividend in sustaining corporate governance and corporate social responsibility on shariah compliance companies performance. European Journal of Molecular and Clinical Medicine, 7(8), 355-370.

Rosly, S.A., Naim, M.A., \& Lahsasna, A. (2017). Measuring Shariah non-compliance risk (SNCR): Claw-out effect of al-bai-bithaman ajil in default. Journal of Islamic Accounting and Business Research, 8(3), 272-283. https://doi.org/10.1108/JIABR-02-2016-0018

Saqib, L., Farooq, M.A., \& Zafar, A.M. (2016). Customer perception regarding Sharīah compliance of Islamic banking sector of Pakistan. Journal of Islamic Accounting and Business Research, 7(4), 282-303. https://doi.org/10.1108/JIABR-08-2013-0031

Satt, H., Bendriouch, F.Z., \& Nechbaoui, S. (2020). The impact of Shariah finance compliance level on the cost of debt. Journal of Islamic Accounting and Business Research, 11(6), 1211-1226. https://doi.org/10.1108/JIABR-04-2018-0056

Sawari, M.F.M., Hassan, R., \& Abdullah, M.F. (2011). Prize-giving to the premium savings certificate holders: A Shari'ah compliance review on the Bank Simpanan Nasional (National Savings Bank) in Malaysia. International Journal of Islamic and Middle Eastern Finance and Management, 4(3), 259-270. https://doi.org/10.1108/17538391111166485

Shamsudheen, S.V., \& Rosly, S.A. (2020). Measuring ethical judgement on ethical choice in an ethical system: A confirmatory study on Islamic banks in UAE. International Journal of Islamic and Middle Eastern Finance and Management, 14(2), 301-316. https://doi.org/10.1108/ IMEFM-03-2018-0112

Sharif, S., Ahson, S., \& Noor, H. (2020). Al Meezan Investment Management Limited: Evolution of Sharīah-compliant mutual funds. Emerald Emerging Markets Case Studies, 10(4), 1-41. https://doi.org/10.1108/eemcs-12-2019-0339

Sholihin, M. (2020). Fatwa antara Makharij Fiqhiyah dan market needs: Eklektisisme pragmatis di balik Fatwa DSN MUI di Indonesia. Al-Istinbath : Jurnal Hukum Islam, 5(1), 71. https://doi. org/10.29240/jhi.v5i1.1412

Sulaiman, Y., Jamil, N.A.M., Othman, A.R., \& Musa, R. (2020). The influence of green marketing, syariah compliance, customer's environmental awareness and customer's satisfaction towards Muslim consumer purchasing behaviour in Kedah. WSEAS Transaction on Business and Economics, 17, 195-204. https://doi.org/10.37394/23207.2020.17.21

Suzuki, Y., \& Miah, M.D. (2021). Shari'ah-compliant benchmark and Shari'ah-based "raf' al-haraj" benchmark on prohibition of riba. International Journal of Islamic and Middle Eastern Finance and Management, 14(1), 151-163 https://doi.org/10.1108/IMEFM-11-2019-0490

Tajuddin, A.H., Mohd Rashid, R., Khaw, K.L.-H., \& Che Yahya, N. (2019). Shariah-compliant status and investors' demand for IPOs: The effects of information asymmetry. International Journal 
of Islamic and Middle Eastern Finance and Management, 12(4), 489-508. https://doi. org/10.1108/IMEFM-01-2019-0026

Trakic, A. (2020). Shari'ah compliance in Islamic finance contracts: The Malaysian constitutional dilemma. Oxford University Commonwealth Law Journal, 20(2), 289-309. https://doi.org/10. 1080/14729342.2020.1812025

Ullah, H. (2014). Shari'ah compliance in Islamic banking: An empirical study on selected Islamic banks in Bangladesh. International Journal of Islamic and Middle Eastern Finance and Management, 7(2), 182-199. https://doi.org/10.1108/IMEFM-06-2012-0051

Umar, Z., Shahzad, S.J.H., Ferrer, R., \& Jareño, F. (2018). Does Shariah compliance make interest rate sensitivity of Islamic equities lower? An industry level analysis under different market states. Applied Economics, 50(42), 4500-4521. https://doi.org/10.1080/00036846.2018.145 8191

Yahya, Y., \& Mahzan, N. (2011). The role of internal auditing in ensuring governance in Islamic Financial Institutions (IFIs). Proceedings of the 16th International Business Information Management Association Conference, IBIMA 2011, 4, 1843-1848. https://www.scopus.com/ inward/record.uri?eid=2-s2.0-84905082259\&partnerID $=40 \& \mathrm{md5}=8299 \mathrm{eec} 12351 \mathrm{a} 2 \mathrm{c} 1 \mathrm{cb} 3 \mathrm{~b} 46$ f0e57cb5df

Zatadini, N., \& Syamsuri, S. (2018). Konsep Maqashid Syariah menurut Al-Syatibi dan kontribusinya dalam kebijakan fiskal. Al-Falah: Journal of Islamic Economics, 3(2), 1-16. https://doi. org/10.29240/alfalah.v3i2.587

Zhang, W., Sun, T., Wang, Z., Kumar, V.R., \& Ma, Y. (2019). Does faith have impact on investment return: Evidence from REITS. International Journal of Strategic Property Management, 23(6), 378-389. https://doi.org/10.3846/ijspm.2019.10428 
